\title{
Zinc effects on mouse spermatozoa and in-vitro fertilization
}

\author{
S. Aonuma, M. Okabe, M. Kawaguchi and Y. Kishi \\ Faculty of Pharmaceutical Sciences, Osaka University, 1-6 Yamadaoka, Suitashi, Osaka, \\ Japan
}

\begin{abstract}
Summary. The fertilizing ability of mouse epididymal and capacitated spermatozoa was tested by mixing with normal or zona-free ova. In the presence of $\mathrm{Zn}^{2+}$, the epididymal spermatozoa failed not only to penetrate the zona pellucida but also to fuse with zone-free ova, while no effect was observed on capacitated spermatozoa.

$\mathrm{Zn}^{2+}$ also inhibited fertilization with spermatozoa preincubated in $\mathrm{Ca}^{2+}$-free medium. However, shortly after the addition of $\mathrm{Ca}^{2+}$ to the preincubated spermatozoa, $\mathrm{Zn}^{2+}$ lost its fertilization inhibitory activity.
\end{abstract}

\section{Introduction}

Prior to fertilization, spermatozoa undergo a series of physiological and morphological changes in the female reproductive tract (Austin, 1951; Chang, 1951). The zona pellucida is believed to help block polyspermy and protect the vitellus (Piko, 1969; Aonuma, Okabe, Kawai \& Kawaguchi, 1978a). Studies to examine the interaction between spermatozoa and the zona pellucida (Hartmann \& Gwatkin, 1971; Hartmann, Gwatkin \& Hutchinson, 1972; Hartmann \& Hutchinson, $1974 \mathrm{a}, \mathrm{b}$ ) have suggested that sperm capacitation may be a process of acquiring the capacity to penetrate the zona pellucida (Austin, 1965; Pavlok \& McLaren, 1972).

We have shown that $\mathrm{Zn}^{2+}$, which exists in high concentrations in the prostate, semen and spermatozoa, suppressed mouse sperm capacitation in vitro (Aonuma, Okabe \& Kawaguchi, 1978b). The present study involved the suppression of capacitation by $\mathrm{Zn}^{2+}$ and investigation of the fertilizing ability of the spermatozoa when incubated with zona-free ova.

Calcium is known to be essential for the fusion of spermatozoa and ova (Iwamatsu \& Chang, 1971; Johnson, 1975; Miyamoto \& Ishibashi, 1975). Yanagimachi \& Usui (1974) claimed that spermatozoa failed to undergo an acrosome reaction and the activation process in a calcium-free medium. Therefore, the fertilizing ability of spermatozoa preincubated in a calcium-free medium was also examined in the presence of $\mathrm{Zn}^{2+}$.

\section{Materials and General Methods}

The spermatozoa were obtained from the cauda epididymidis of mature DDY mice (weighing $35-40 \mathrm{~g}$ ) as previously reported (Aonuma et al., 1978b). A modified Krebs-Ringer-bicarbonate (m-KRB) solution (Toyoda, Yokoyama \& Hoshi, 1971) was changed by altering the $\mathrm{pH}$ from 7.4 to 8.0 (Aonuma, Okabe \& Kawai, 1976) and the $\mathrm{Ca}^{2+}$-free medium was prepared by deletion of $\mathrm{CaCl}_{2}$. The $\mathrm{Zn}^{2+}$-containing medium was prepared by adding $\mathrm{ZnCl}_{2}$. For the 24-h incubation of the ova, the $\mathrm{pH} 7.4$ medium was used. The ova were obtained from 4-5-week-old DDY mice injected intraperitoneally with 5 i.u. PMSG (Teikoku Zoki) $48 \mathrm{~h}$ before 
administration of 5 i.u. hCG (Teikoku Zoki). The mice were killed at 14-16 h after hCG injection and the ova in cumulus cell clots were recovered by puncturing the ampullar portion of the oviduct with a needle. The collected ova were washed twice with $10 \mathrm{ml}$ medium and used for the experiments. The zona-free ova were obtained by treating the ova with $0.1 \%$ bovine testicular hyaluronidase (Sigma) followed by $0.1 \% \alpha$-chymotrypsin (Sigma), each at $37^{\circ} \mathrm{C}$, for $10 \mathrm{~min}$ in $\mathrm{m}-\mathrm{KRB}$. After two washes with fresh medium, the zona-free ova were collected and used for the experiments as indicated.

Throughout the experiments, $50 \mu \mathrm{l}$ aliquots of the sperm suspension $\left(0.8-1.2 \times 10^{6}\right.$ spermatozoa $/ \mathrm{ml}$ ) were added to ova in $0.4 \mathrm{ml} \mathrm{m}-\mathrm{KRB}$. After incubation of normal ova, hyaluronidase $(0 \cdot 1 \%$ final concentration) was added to ova in $\mathrm{m}-\mathrm{KRB}$. The cumulus cells were removed rapidly by agitating the ova with a pipette. All ova were immediately examined for sperm penetration, formation of pronuclei and later stages of cleavage, as appropriate for the incubation time, with phase-contrast microscopy without staining.

\section{Detailed Methods and Results}

Effect of $\mathrm{Zn}^{2+}$ on the fertilization of mouse ova in vitro

In Exp. I, the fertilizing abilities of the epididymal spermatozoa and the capacitated spermatozoa were compared in the presence of $250 \mu \mathrm{M}-\mathrm{Zn}^{2+}$. As shown in Table 1, few epididymal spermatozoa succeeded in penetrating the zona pellucida and/or forming pronuclei, but capacitated spermatozoa were not affected by the presence of $\mathrm{Zn}^{2+}$. In Exp. II, epididymal or capacitated spermatozoa were introduced to zona-free ova and incubated for $5 \mathrm{~h}$ in the presence of $250 \mu \mathrm{M}-\mathrm{Zn}^{2+}$. The capacitated spermatozoa penetrated the zona-free ova and formed pronuclei, but values for the epididymal spermatozoa were very low. In Exp. III, 1.5 or $5 \mathrm{~h}$ after sperm-egg mixing, ova were washed with m-KRB (pH 7.4) and transferred to $0.4 \mathrm{ml}$ fresh $\mathrm{m}-\mathrm{KRB}\left(\mathrm{pH}\right.$ 7.4). $\mathrm{Zn}^{2+}$ was then added and the incubation was continued until $24 \mathrm{~h}$ after insemination: there was no development to the 2-cell stage.

Table 1. Effects of $\mathrm{Zn}^{2+}$ on fertilization of mouse eggs in vitro

\begin{tabular}{|c|c|c|c|c|c|}
\hline \multirow[b]{3}{*}{ Exp. } & \multirow[b]{3}{*}{ Spermatozoa } & \multirow[b]{3}{*}{ Ova } & \multirow{3}{*}{$\begin{array}{c}\mathrm{Zn}^{2+} \\
\text { addition }\end{array}$} & \multicolumn{2}{|c|}{ Fertilization (\%) } \\
\hline & & & & \multicolumn{2}{|c|}{ Time after insemination } \\
\hline & & & & $1.5 \mathrm{~h}^{\mathrm{d}}$ & $5 \mathrm{~h}^{\mathrm{e}}$ \\
\hline I & $\begin{array}{l}\text { Capacitated } \\
\text { Epididymal } \\
\text { Capacitated }\end{array}$ & $\begin{array}{l}\text { Normal } \\
\text { Normal } \\
\text { Normal }\end{array}$ & $\begin{array}{l}- \\
+a \\
+a\end{array}$ & $\begin{array}{c}62 \pm 8 \\
0 \\
55 \pm 9\end{array}$ & $\begin{array}{c}55 \pm 10 \\
7 \pm 1^{*} \\
55 \pm 4\end{array}$ \\
\hline II & $\begin{array}{l}\text { Capacitated } \\
\text { Epididymal } \\
\text { Capacitated }\end{array}$ & $\begin{array}{l}\text { Zona-free } \\
\text { Zona-free } \\
\text { Zona-free }\end{array}$ & $\begin{array}{l}- \\
+a \\
+a\end{array}$ & - & $\begin{array}{r}66 \pm 7 \\
5 \pm 3^{*} \\
50 \pm 12\end{array}$ \\
\hline III & $\begin{array}{l}\text { Epididymal } \\
\text { Epididymal } \\
\text { Epididymal }\end{array}$ & $\begin{array}{l}\text { Normal } \\
\text { Normal } \\
\text { Normal }\end{array}$ & $\begin{array}{l}- \\
++^{b} \\
+^{c}\end{array}$ & \multicolumn{2}{|c|}{$\begin{aligned} 54 & \pm 2 \\
2 & \pm 1^{*}\end{aligned}$} \\
\hline
\end{tabular}

$\mathrm{Zn}^{2+}$ was added to the medium (a) at the time of insemination, (b) at $1.5 \mathrm{~h}$ after insemination and (c) at $5 \mathrm{~h}$ after insemination. Fertilized ova were examined for (d) zona penetration, (e) zona penetration and pronuclei formation, and (f) 2-cell ova. Each value shows mean \pm s.e.m. of 3-5 independent tests; altogether 46-104 ova were examined in each group. * Significantly different from other values in that experiment $(P<0.01)$. 


\section{Effect of $\mathrm{Zn}^{2+}$ on the fertilizing ability of spermatozoa preincubated in $\mathrm{Ca}^{2+}$-free medium}

In Exp. IV, spermatozoa were preincubated in $\mathrm{Ca}^{2+}$-free medium for $40 \mathrm{~min}$. $\mathrm{Ca}^{2+}$ was then added and the spermatozoa were incubated at $37^{\circ} \mathrm{C}$. Aliquots $(50 \mu \mathrm{l})$ were taken from the sperm suspension at 10,20,30 and $40 \mathrm{~min}$ after the addition of $\mathrm{Ca}^{2+}$ and introduced to ova in $\mathrm{Zn}^{2+}$-containing medium. The ova (46-68/group) were examined for fertilization $90 \mathrm{~min}$ after the insemination. The preincubated spermatozoa were still $\mathrm{Zn}^{2+}$-sensitive at $10 \mathrm{~min}$ after the $\mathrm{Ca}^{2+}$ addition (no eggs fertilized). At $20 \mathrm{~min}, 26 \pm 10 \%$ of eggs were fertilized, and at 30 and 40 min the values were $42 \pm 12$ and $46 \pm 5 \%$ respectively. In Exp. V, spermatozoa were preincubated in $\mathrm{Ca}^{2+}$-free medium for $40 \mathrm{~min}$ and introduced to the ova in 4 test-tubes containing m-KRB (approximately 50 ova in each group). These 4 tubes were incubated for 10 , 20,30 and $40 \mathrm{~min}$, respectively. Hyaluronidase $(0.1 \%$ final concentration) was added to each tube at the end of the incubation. The fertilization percentages were $29 \pm 9,42 \pm 7,52 \pm 13$ and $52 \pm 10$ at $10,20,30$ and 40 min respectively.

\section{Discussion}

Aonuma et al. (1978b) reported that $\mathrm{Zn}^{2+}$ inhibited penetration of the fresh epididymal spermatozoa into the ova, but did not inhibit penetration of the capacitated spermatozoa. Thus, the inhibitory activity of $\mathrm{Zn}^{2+}$ on the fertilization of mouse ova in vitro is not due to inhibition of sperm penetration, but to inhibition of sperm capacitation. However, since the observation was carried out $90 \mathrm{~min}$ after the insemination, the possibility that $\mathrm{Zn}^{2+}$ simply delayed capacitation could not be excluded. In the current studies, ova were inseminated by epididymal spermatozoa and incubated in the presence of $\mathrm{Zn}^{2+}$. After incubation for $5 \mathrm{~h}$ few ova were penetrated, suggesting that the effect of $\mathrm{Zn}^{2+}$ on sperm capacitation is based on the blocking rather than the delaying of the capacitation process. In spite of the presence of $\mathrm{Zn}^{2+}$, ova penetrated by capacitated spermatozoa developed to the pronuclear stage, indicating that $\mathrm{Zn}^{2+}$ has no effect on the fusion of capacitated spermatozoa with ova (Table 1, Exp. I). However, the zona pellucida might decrease the $\mathrm{Zn}^{2+}$ concentration in the perivitelline space. The experiment using zona-free ova inseminated by capacitated spermatozoa in the presence of $\mathrm{Zn}^{2+}$ (Table 1, Exp. II) confirmed that $\mathrm{Zn}^{2+}$ had no influence on the sperm-ova fusion. When zona-free ova were inseminated by epididymal spermatozoa under the same conditions, few pronuclei were observed during a 5-h incubation. This strongly suggests that the spermatozoa must be capacitated before they can fuse with the ova.

The fusion of spermatozoa to zona-free ova has been studied in mice (Pavlok \& McLaren, 1972; Wolf, Inoue \& Stark, 1976) and many other mammals (Yanagimachi, 1978), and the results indicate that plasma membrane in the post-equatorial segment is important for fusion. A change of membrane fluidity in the postnuclear cap region during capacitation has also been reported (Barros \& Franklin, 1968; Barros, 1974; Barros \& Berrios, 1977; Barros \& Herrera, 1977; Yanagimachi, 1978). It is therefore likely that $\mathrm{Zn}^{2+}$ inhibits the membrane change in this region. However, it has also been suggested that the sperm trypsin-like enzyme participates in an acrosome reaction (Meizel \& Lui, 1976; Lui \& Meizel, 1979) and that the acrosomal enzymes may play a role in the modification of the postnuclear cap region (Barros, 1974). It remains to be determined whether or not the effect of $\mathrm{Zn}^{2+}$ on sperm-ova fusion is independent of an acrosome reaction. Since the zona pellucida was removed by enzymic treatment, an artificial change in the membrane might be inevitable. However, according to Hirao \& Yanagimachi (1978), zona-free ova prepared in various ways (including enzymic treatment) showed no difference in fertilizing ability.

As shown in Exp. IV, spermatozoa preincubated in $\mathrm{Ca}^{2+}$-free medium remained sensitive to $\mathrm{Zn}^{2+}$, but lost this sensitivity after $20 \mathrm{~min}$ when incubated in normal medium. This suggests that the spermatozoa had not accomplished capacitation during the preincubation in $\mathrm{Ca}_{202}^{2+}$-free 
medium and needed to spend about $30 \mathrm{~min}$ in the normal medium to become capacitated. However, when spermatozoa preincubated in the $\mathrm{Ca}^{2+}$-free medium were introduced to the ova in the normal medium, sperm penetration occurred within $10 \mathrm{~min}$ after the insemination, indicating that the spermatozoa preincubated in $\mathrm{Ca}^{2+}$-free medium achieved capacitation before the spermatozoa had lost their sensitivity to $\mathrm{Zn}^{2+}$. It is not clear how many steps are involved in the capacitation process, or in how many steps $\mathrm{Zn}^{2+}$ has a regulatory activity. However, based on the results showing that the $\mathrm{Zn}^{2+}$ has no effect on capacitated spermatozoa, an interaction between the decapacitation factor(s) which is (are) released from the spermatozoa during capacitation (Aonuma et al., 1973) and the $\mathrm{Zn}^{2+}$ is highly probable.

\section{References}

Aonuma, S., Mayumi, T., Suzuki, K., Noguchi, T., Iwai, M. \& Okabe, M. (1973) Studies on sperm capacitation. I. The relationship between a guineapig sperm-coating antigen and capacitation phenomenon. J. Reprod. Fert. 35, 425-432.

Aonuma, S., Okabe, M. \& Kawai, Y. (1976) In vitro fertilization of mouse ova. I. J. Pharm. Soc. Japan 96, 1307-1312.

Aonuma, S., Okabe, M., Kawai, Y. \& Kawaguchi, M. (1978a) The change of solubility properties of zona pellucida to proteases related to fertilizability of mouse ova in vitro. Chem. Pharm. Bull. 26, 405-410.

Aonuma, S., Okabe, M. \& Kawaguchi, M. (1978b) The effect of zinc ions on fertilization of mouse ova in vitro. J. Reprod. Fert. 53, 179-183.

Austin, C.R. (1951) Observation on the penetration of the sperm into mammalian egg. Aust.J. sci. Res. B 4, 581 .

Austin, C.R. (1965) Fertilization. Prentice-Hall, Englewood Cliffs, New Jersey.

Barros, C. (1974) Capacitation of mammalian spermatozoa. In Physiology and Genetics of Reproduction, Part B, pp. 3-24. Eds E. M. Coutinho \& F. Fuchs. Plenum Press, New York.

Barros, C. \& Berrios, M. (1977) Is the activated spermatozoa really capacitated? J. exp. Zool. 201, 65-72.

Barros, C. \& Franklin, L.E. (1968) Behavior of the gamete membrane during sperm entry into the mammalian egg. J. Cell Biol. 37, c13-c18.

Barros, C. \& Herrera, E. (1977) Ultrastructural observations of the incorporation of guinea-pig spermatozoa into zona-free hamster oocytes. J. Reprod. Fert. 49, 47-50.

Chang, M.C. (1951) Fertilizing capacity of spermatozoa deposited into the Fallopian tubes. Nature, Lond. 168,697

Hartmann, J.F. \& Gwatkin, R.B.L. (1971) Alteration of sites on the mammalian sperm surface following capacitation. Nature, Lond. 234, 479-481.

Hartmann, J.F. \& Hutchinson, C.F. (1974a) Nature of the prepenetration contact interaction between hamster gametes in vitro. J. Reprod. Fert. 36, 49-57.

Hartmann, J.F. \& Hutchinson, C.F. (1974b) Contact between hamster spermatozoa and the zona pellucida releases a factor which influences early binding stages. J. Reprod. Fert. 37, 61-66.
Hartmann, J.F., Gwatkin, R.B.L. \& Hutchinson, C.F. (1972) Early contact interactions between mammalian gametes in vitro: evidence that the vitellus influences adherence between sperm and zona pellucida. Proc. natn. Acad. Sci. U.S.A. 69, 2767-2769.

Hirao, Y. \& Yanagimachi, R. (1978) Effects of various enzymes on the ability of hamster egg plasma membranes to fuse with spermatozoa. Gamete Res. 1, 3-12.

Iwamatsu, T. \& Chang, M.C. (1971) Factors involved in the fertilization of mouse eggs in vitro. J. Reprod. Fert. 26, 197-208.

Johnson, M.H. (1975) The macromolecular organization of membranes and its bearing on events leading up to fertilization. J. Reprod. Fert. 44, 167-184.

Lui, C.W. \& Meizel, S. (1979) Further evidence in support of a role for hamster sperm hydrolytic enzymes in the acrosome reaction. J.exp. Zool. 207, 173-186.

Meizel, S. \& Lui, C.W. (1976) Evidence for the role of a trypsin-like enzyme in the hamster sperm acrosome reaction (1). J. exp. Zool. 195, 137-144.

Miyamoto, H. \& Ishibashi, T. (1975) The role of calcium ions in fertilization of mouse and rat eggs in vitro. $J$. Reprod. Fert. 45, 523-526.

Pavlok, A. \& Mclaren, A. (1972) The role of cumulus cells and the zona pellucida in fertilization of mouse eggs in vitro. J. Reprod. Fert. 28, 91-97.

Piko, L. (1969) Gamete structure and sperm entry in mammals. In Fertilization, Vol. III, pp. 325-403. Eds L. B. Metz \& A. Monroy. Academic Press, New York.

Toyoda, Y., Yokoyama, M. \& Hoshi, T. (1971) Studies on the fertilization of mouse eggs in vitro. II. Effect of in vitro preincubation of spermatozoa on time of sperm penetration of mouse eggs in vitro. Jap. J. Anim. Reprod. 16, 152-157.

Wolf, D.P., Inoue, M. \& Stark, R.A. (1976) Penetration of zona-free mouse ova. Biol. Reprod. 15, 213-221.

Yanagimachi, R. (1978) Sperm-egg association in mammals. In Current Topics in Developmental Biology, Vol. 12, pp. 83-105. Eds A. A. Moscona \& A. Monroy. Academic Press, New York.

Yanagimachi, R. \& Usui, N. (1974) Calcium dependence of the acrosome reaction and activation of guinea pig spermatozoa. Expl Cell Res. 89, 161-174. 